This item was submitted to Loughborough's Research Repository by the author.

Items in Figshare are protected by copyright, with all rights reserved, unless otherwise indicated.

\title{
UK microgeneration. Part I: policy and behavioural aspects
}

PLEASE CITE THE PUBLISHED VERSION

http://dx.doi.org/10.1680/ener.2009.162.1.23

PUBLISHER

(C) ICE Publishing Ltd.

\section{VERSION}

VoR (Version of Record)

LICENCE

CC BY-NC-ND 4.0

\section{REPOSITORY RECORD}

Bergman, Noam, Adam Hawkes, Daniel J.L. Brett, Philip Baker, John P. Barton, Richard E. Blanchard, Nigel P. Brandon, et al.. 2019. "UK Microgeneration. Part I: Policy and Behavioural Aspects". figshare. https://hdl.handle.net/2134/15419. 
This item was submitted to Loughborough's Institutional Repository (https://dspace.lboro.ac.uk/) by the author and is made available under the following Creative Commons Licence conditions.

\section{creative
commons}

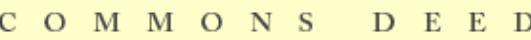

Attribution-NonCommercial-NoDerivs 2.5

You are free:

- to copy, distribute, display, and perform the work

Under the following conditions:

Attribution. You must attribute the work in the manner specified b the author or licensor.

Noncommercial. You may not use this work for commercial purposes.

No Derivative Works. You may not alter, transform, or build upon this work.

- For any reuse or distribution, you must make clear to others the license terms of this work.

- Any of these conditions can be waived if you get permission from the copyright holder.

Your fair use and other rights are in no way affected by the above.

This is a human-readable summary of the Leqal Code (the full license).

\section{Disclaimer 만}

For the full text of this licence, please go to: http://creativecommons.org/licenses/by-nc-nd/2.5/ 


Proceedings of the Institution of
Civil Engineers
Energy 162
February 2009 Issue ENI
Pages 23-36
doi: $10.1680 /$ ener.2009.162.1.23
Paper 800045
Received 22/09/2008
Accepted 28/01/2009
Keywords:
energy/government/social impact

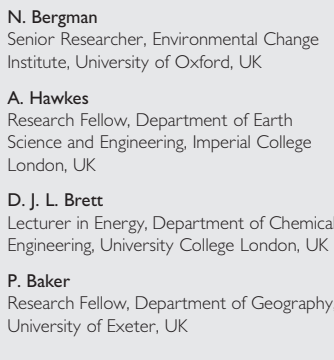

J. Barton
Research Associate, CREST, University of
Loughborough, UK
R. Blanchard
Flexible and Distance Learning Coordinator,
CREST, University of Loughborough, UK
N. P. Brandon
Shell Professor of Sustainable Development
in Energy, Imperial College London, UK
D. Infield
Professor of Renewable Energy, Institute of
Energy and Environment, University of
Strathclyde, Glasgow, UK

C. Jardine
Senior Researcher, Environmental Change
Institute, University of Oxford, UK
N. Kelly
RCUK Academic Fellow, Energy Systems
Research Unit, University of Strathclyde,
Glasgow, UK
M. Leach
Professor of Energy and Environmental
Systems, University of Surrey, Guildford, UK
M. Matian
PhD Researcher, Department of Earth
Science and Engineering, Imperial College
London, UK

\section{UK microgeneration. Part I: policy and behavioural aspects}

N. Bergman PhD, A. Hawkes CEng, MEl, D. J. L. Brett PhD, DIC, P. Baker, J. Barton MSc, MA, PhD, R. Blanchard PhD, N. P. Brandon PhD, FREng, D. Infield PhD, CPhys, MlnstP, BWEA, C. Jardine MChem, DPhil, N. Kelly PhD, M. Leach PhD, DIC, CEng, FEl, FRSA, M. Matian MSc, A. D. Peacock, I. Staffell MSc, S. Sudtharalingam MEng and B. Woodman PhD

A critical review of the literature relating to government policy and behavioural aspects relevant to the uptake and application of microgeneration in the UK is presented. Given the current policy context aspiring to zero-carbon new homes by 2016 and a variety of minimum standards and financial policy instruments supporting microgeneration in existing dwellings, it appears that this class of technologies could make a significant contribution to UK energy supply and low-carbon buildings in the future. Indeed, achievement of a reduction in greenhouse gas emissions by $\mathbf{8 0} \%$ (the UK government's 2050 target) for the residential sector may entail substantial deployment of microgeneration. Realisation of the large potential market for microgeneration relies on a variety of interrelated factors such as microeconomics, behavioural aspects, the structure of supporting policy instruments and well-informed technology development. This paper explores these issues in terms of current and proposed policy instruments in the UK. Behavioural aspects associated with both initial uptake of the technology and after purchase are also considered.

\section{INTRODUCTION}

Energy supply and demand is high on the international agenda, with issues such as climate change and energy security potentially having profound societal, environmental and economic consequences. International policy intended to tackle climate change (e.g. the Kyoto protocol) places a requirement on governments to decarbonise the energy supply chain. The 4th Intergovernmental Panel on Climate Change (IPCC) assessment report identified the built environment as having the largest economic potential for mitigation of carbon dioxide emissions. ${ }^{1}$ The residential sector accounts for around a quarter of UK carbon dioxide emissions and low-carbon energy technologies that can be applied in this sector are therefore of particular interest.

Microgeneration is the generation of zero- or low-carbon heat and/or power by individuals, small businesses and communities to meet their own needs. In many situations, local generation has the potential to achieve much higher efficiency, and consequential carbon dioxide and cost savings, by avoiding the losses associated with delivering electrical power via the grid over long distances and/or through the use of both heat and power at the point of use. Microgeneration also has the potential to help combat fuel poverty, add to the diversity of energy supply, offset some of the looming shortfall in centralised generating capacity and avoid the need to replace or extend electricity transmission infrastructure.

A range of microgeneration technologies exist that either harness energy from the environment (small-scale wind turbines, water turbines, heat pumps, solar thermal collectors, solar photovoltaics (PV), etc.) or generate heat and power from a fuel (e.g. internal combustion engines, Stirling engines and fuel cells). There are currently $\sim 100000$ microgeneration installations in the UK. However, with a potential for tens of millions of installations, the uptake of microgeneration needs to be accelerated in order to realise its potential.

This paper is a result of activities within the United Kingdom Energy Research Centre (UKERC) cross-theme research project on microgeneration. ${ }^{2}$ It is the first in a series of 'position papers' dealing with the issues relating to microgeneration, with a particular focus on residential-scale generation in the UK. The issues considered include policy, behavioural aspects of uptake and use, microgeneration technologies, system modelling, techno-economics, integration with the electricity grid, life-cycle analysis, and so on. This paper reviews current and proposed UK policy on microgeneration and the factors influencing human behaviour in its uptake and use.

The interconnection between policy instruments and behavioural aspects is an important research area that has not benefited from detailed attention. Policy is generally focused on uptake; behaviour and usage patterns after uptake are not usually addressed. However, for residential-scale microgeneration, behavioural aspects are key and policy should be formulated with them in mind.

\section{MICROGENERATION POLICY IN THE UK}

\section{I. The general policy environment}

Spurred by international concern regarding climate change, the UK government indicated an aspiration to achieve a $60 \%$ 
reduction in greenhouse gas emissions by 2050 in the 2003 Energy White Paper. ${ }^{3}$ This aspiration has become a requirement in law via the government's recent Climate Change Act. ${ }^{4}$ This act increased the target to $80 \%$, which is more appropriate to prevent atmospheric greenhouse gas concentration levels exceeding those required for climate stabilisation. Approximately 25\% of current UK greenhouse gas emissions are a result of heat and electricity use in the residential sector. ${ }^{5}$ As such, it has become a focus of policy and regulation. Among a variety of measures that could make an impact, microgeneration is considered to be one area that could aid meeting the ambitious emissions reduction targets for the sector in a cost-effective manner, while also providing a measure of energy security through diversity and geographical distribution.

The past decade has seen substantial developments in both broad UK energy policy and specific policy and regulation relating to microgeneration, complemented by significant technological advances in microgeneration systems. This section presents a critical review of current and proposed policy and regulation relating to microgeneration in the UK. A wide range of measures exists, some with obtuse relationship to the benefit or detriment of commercialisation prospects for microgeneration. Only those measures perceived to have a direct bearing on commercial uptake and application patterns of microgeneration by owner-operators are presented. For example, support measures such as academic and commercial research and development funding are not presented here.

\subsection{Policy instruments for microgeneration}

2.2.1. Broad policy instruments and related activity. The Climate Change and Sustainable Energy Act 2006 included a number of broad measures relevant to microgeneration. ${ }^{6}$ Key among these is a provision to allow the secretary of state to set targets for national uptake of microgeneration, and to require electricity suppliers to offer terms for buyback of electricity. These measures are positive general steps to encourage industry investment and improve the economic case for microgeneration. They are related to a number of other activities under way in government and government agencies, and it remains to be seen what action will transpire. It is likely that the setting of targets will only come about if an economic case can be made for microgeneration and, for many technologies, that may in turn depend upon the provision of payback for exported electricity or generated electricity by suppliers.

Among activities related to the broad microgeneration policy, probably the most challenging are those related to connection, metering, balancing and settlement. Recent actions related to this issue are that

(a) connection rules have been streamlined ${ }^{7}$

(b) regulations governing safety have been established ${ }^{8}$

(c) the requirement for half-hourly metering has been removed for small systems. ${ }^{9}$

A number of issues still remain, many of which are related to the simplicity and logistics of microgenerator installation and operation. Many of these issues relate to data flows within the balancing and settlement code (BSC), in order to allow microgeneration export to participate in system balancing effectively and to be fairly settled. Data flow issues should be resolvable, albeit at some expense. Arguably, metering costs, etc. will cost more than the value of export for some microgenerators, although metering issues are an important behavioural concern, as discussed in Section 3.6.

Perhaps the most challenging issue regarding balancing and settlement is that of creating standardised profile classes for dwellings with microgenerators (and for microgeneration export). Standard profile classes are a tool used in balancing and settlement where half-hourly metered data are not available. They are expensive to create and, for microgeneration, may be inaccurate as generation profiles may vary significantly even between technologies of the same type. This not only creates difficulty regarding fair settlement for each generator but also has implications regarding effective low-cost balancing of the system in real time. In the future, these standard profile classes may be replaced by a smart metering and information technology solution.

As the amount of microgeneration increases and the amount of large, central generating capacity deceases, it will become necessary for microgeneration to be controllable in order to maintain a stable electricity system. The roles of system balancing, local voltage control and phase balancing are particularly important. For these reasons, smart metering and two-way communication with the supplier will become necessary to enable microgeneration to meet the needs of the grid, and for householders to be financially rewarded for controlling microgeneration in this way.

2.2.2. Specific financial policy instruments. The most targeted existing policy to support the uptake of microgeneration is the microgeneration strategy. ${ }^{10}$ The primary policy instrument of this strategy is the low-carbon buildings programme (LCBP), which provided $£ 86$ million of treasury funding to be applied in grant support for new microgeneration installations. £18 million of this was available for the 'households' stream of the LCBP, beginning in March 2006, and continuing for three years or until funding runs out. At the time of writing, approximately $£ 7$ million has been committed to support over 7000 new microgeneration installations. Technologies supported in the households stream are micro-wind, micro-hydro, solar PV, solar hot water, heat pumps, biomass room heaters and biomass boilers. Micro combined heat and power (micro-CHP) was not supported at the time of writing but was listed as a technology that will be supported. ${ }^{11}$

There are two further policy instruments that aid in providing capital cost reductions to potential owner-operators: the carbon emissions reduction target (CERT) for energy suppliers and valueadded tax (VAT) relief for the purchase of energy-saving items. Both these instruments are directed at carbon dioxide saving actions in general. Microgeneration has been included in the list of items supported in the predecessor to CERT, the 2005-2008 energy efficiency commitment. ${ }^{12}$ It is also included in CERT ${ }^{13}$ as a market transformation action 'where the authority approves the promotion of microgeneration'. If this requirement is met, microgeneration can provide up to 12\% of a supplier's CERT (after uplift of 50\% carbon dioxide reduction for market transformation actions is applied). Some microgeneration measures have been supported through VAT relief since $2001^{14}$ and others have also qualified for this support via various statutory instruments since $2004 .^{15-17}$ 
The CERT is a regulatory measure directed at energy suppliers (i.e. the retail element of the liberalised energy market), requiring them to perform 'qualifying actions' that cumulatively provide carbon dioxide emissions reduction from the residential sector over a 'commitment period' equal to (or greater than) their target, as set by the gas and electricity market regulator, the Office of Gas and Electricity Markets (Ofgem). The CERT is a development from previous energy-efficiency commitments (EECs), which had a very similar structure, although each three-year commitment period since 2002 has approximately doubled the required carbon dioxide savings. Qualifying actions are typically energyefficiency measures such as loft and cavity wall insulation or energy-efficient lighting, each of which has a specific carbon dioxide saving associated with it (set by Ofgem). This mechanism essentially emulates a cap-and-trade system - that is, the carbon dioxide emissions reduction target is established and suppliers are then allowed to find the cheapest way to achieve that target, including encouraging uptake of qualifying actions, and trade of actions and commitments among themselves. (While the system emulates cap-and-trade, it is not identical. It does not genuinely cap carbon dioxide emissions, but rather provides for a reduction over a business-as-usual scenario. Therefore actual emissions reduction achieved at the end of a period with respect to the beginning of the period is difficult to quantify, and the overall outcome may indeed be an emissions increase.) Typically, a supplier performs a qualifying action by subsidising the cost of installation and then claiming the associated carbon dioxide savings. According to the CERT consultation, ${ }^{18}$ some of the cheapest measures are loft and cavity wall insulation, with lifetime carbon dioxide savings and suppliers' average contribution to total cost of $13 \cdot 46 \mathrm{tCO}_{2} / £ 261$ and $4 \cdot 39 \mathrm{tCO}_{2} /$ $£ 227$, respectively. This equates to an implied cost of $£ 20$ and $£ 52$ per tonne of carbon dioxide, respectively. As a number of different qualifying actions will be used by suppliers to meet the target, the average cost of these actions can be determined, resulting in an implied cost per tonne of carbon dioxide reduction. The remainder of this analysis assumes that the implied cost of carbon dioxide is $\mathrm{f20/t}$ (i.e. near the carbon saving cost of average loft insulation).

Following the reduction of VAT for residential fuel and electricity consumption, VAT relief for 'energy-saving items' has been provided in the UK since 1997 in order to align incentives to save energy (and avoid climate change) with incentives to circumvent fuel poverty. This incentive cuts the VAT rate on selected items from the usual $17 \cdot 5 \%$ to $5 \%$. The initial list of items included energy-efficiency measures such as insulation, and some microgeneration measures were subsequently added (wind turbines, solar PV and water turbines). Ground, air and water source heat pumps, micro-CHP and biomass boilers have also been added to the list of supported items. ${ }^{15-17}$ VAT relief provides capital cost reduction to these measures, regardless of how/where/ when they are applied.

Three other specific financial incentives exist for microgeneration owner-operators

(a) income tax exemption for revenue from microgeneration export

(b) renewable obligations certificate (ROC) generation ${ }^{19,20}$

(c) a time-limited stamp duty exemption applied to sale of zerocarbon dwellings. $^{21}$
However, none of these measures is likely to have a significant impact on the economic case for investment. Income tax exemption is a useful simplifying measure, as it means that the owner-operator may not be required to complete a taxation selfassessment each year. While no detailed calculation is performed here, the authors believe the net economic impact (on owneroperator economics and on public revenue from taxation) would be minimal as monies paid in tax on export revenues would be somewhat balanced by monies received as tax refunds for equipment depreciation and fuel costs. What portion of capital investment could be depreciated is debatable, as the device's application is split between personal use (for heating and/or electricity) and commercial purposes. Additionally, if a large number of devices were in operation, the impact on public revenue may become more significant, and this measure may need alteration. A method where taxation is collected at source (i.e. by the supplier), similar to that applied for personal interest payments in the UK banking system, may be more appropriate in that case.

Stamp duty exemption for the sale of 'zero-carbon' dwellings will probably provide little incentive for microgeneration uptake, because the cost of making a dwelling zero-carbon will usually exceed the value of the incentive. Indeed, stamp duty exemption appears to be a short-lived incentive, being time-limited to five years (after which it will be reassessed).

Notwithstanding this issue, the use of microgeneration is currently the only way to achieve truly 'zero-carbon' status as the dwelling must usually export electricity to the grid and receive credit for displaced carbon dioxide emissions to be truly zero-carbon. It should be noted that 'zero-carbon' here refers to a dwelling emissions rate (DER) less than or equal to zero, as calculated under the standard assessment procedure (SAP) 2005 methodology (see Section 2.2.3). This methodology only considers calculated carbon dioxide emissions from energy use for heating, ventilation and lighting. Electricity from other sources is not included, and as such the dwelling need not be truly zero-carbon to achieve 'zerocarbon' status.

2.2.3. Building regulations and the Merton rule. Probably the most important policy instrument discussed here is building regulations. This discussion covers only English and Welsh building regulations, although issues are broadly reflected across the UK and the SAP is applied universally. Over the past few decades, the energy performance standard required in part $\mathrm{L}^{22,23}$ of the building regulations for new build and refurbishment of existing stock has increased dramatically, although questions have been raised regarding weak compliance with part L in comparison with other regulations. ${ }^{24}$

The trend of tightening building regulations is set to continue, with assessment of new buildings against an enhanced standard set out in the code for sustainable homes ${ }^{25}$ to become mandatory. The code for sustainable homes sets out a points-based system for evaluating a dwelling, with points allocated for various aspects of sustainability, along with certain minimum standards in specific areas (such as energy performance). The code incorporates six levels of sustainability, ranging from a 'one star' rating corresponding to slightly better than current building regulations to 'six stars' corresponding to the highest level of sustainability. The government has indicated that all new dwellings be built to a 'truly zero-carbon' standard from 2016. 'Truly zero-carbon' 
means that zero net carbon dioxide emissions arise from energy use/generation in the dwelling. This corresponds to 'six star' level in the code. 'Five star' level corresponds to 'zero carbon' for the SAP 2005 building regulations standard.

Microgeneration within the dwelling is currently the only method by which code level 5 zero-carbon status can be achieved, and microgenerators exporting electricity to the network would normally be required to displace emissions related to on-site energy consumption and thereby meet code level 6, truly zerocarbon. It is important to note that several microgenerators will generally be required in each dwelling to meet the level 5 and level 6 zero-carbon standards of the code for sustainable homes.

The energy performance aspects of the code would be implemented through building regulations, and therefore would be calculated using a new version of the SAP methodology. The current $\mathrm{SAP}^{26}$ includes microgeneration as a measure that can be used towards carbon dioxide savings where generated electricity is assumed to displace grid emissions at a rate of $0.568 \mathrm{~kg} / \mathrm{kWh}$ (while electricity consumption is assumed to embody only $0 \cdot 422 \mathrm{~kg} / \mathrm{kWh}$ ). The different emissions factors applied for consumption versus on-site production of electricity are contentious. The 0.422 figure is based on the government's long-term projections for the average mix of grid electricity from 2005 to 2010. The 0.568 figure is based on the 1998-1999 marginal mix of generating plant plus a factor to account for new build from 2005 to 2010, assuming that it would be combined cycle gas turbines. This methodology has been challenged and will likely be revised.

The Merton rule has also proven to be an important aspect of governance related to microgeneration. It is a planning policy requirement imposed by local councils requiring a certain percentage of renewable energy (or expected carbon dioxide reduction) in any new development above a prescribed size. This translates to a strengthening of the building regulations in specific developments in that they must meet certain additional criteria. The Merton rule, initially imposed by the London Borough of Merton, requires 10\% of energy in new developments of ten or more units (or above $1000 \mathrm{~m}^{2}$ ) to come from renewable sources. Very similar approaches have since been adopted by a significant portion of local councils; central government has encouraged its adoption, making renewable energy (often delivered via microgeneration as opposed to community or centralised schemes) a key aspect of many new developments. The relative efficacy of central government versus local or regional approaches has since become an interesting topic of debate, with early indications suggesting that while centralised strategy is necessary, local approaches are potentially much more effective in realising microgeneration installations. The primary criticism of the Merton rule is that some implementations can be technology-deterministic, and may not be the cheapest way to deliver carbon dioxide reductions. Furthermore, microgeneration capacity is determined at the design stage; once the building is in use the 10\% target may not be met in practice due to the behaviour of its occupants.

\subsection{Critical analysis of policy instruments}

Clearly, there are a wide variety of supporting mechanisms for microgeneration, ranging from direct grant support, through to broad aspirational support such as targets. The combination of raising minimum standards through building regulations while supporting commercial investment through actions to reduce capital cost could probably be effective in terms of uptake, but it may not lead to appropriate usage patterns for the devices once they are installed. Additionally, policy mechanisms are sometimes misdirected, and the wide range of actions can lead to conflicts or overlaps that are confusing to residential owneroperators who generally prefer simple one-stop-shop solutions.

Table 1 makes an estimate of the average level of 'societal' support available for selected microgeneration technologies through the three primary financial policy instruments - the LCBP, the CERT and VAT relief. Total installed cost figures are approximated from a variety of sources, with variations according to LCBP data and the authors' experience. Importantly, microgeneration systems that can be classified as home heating solutions - where they can entirely replace the existing conventional alternative (usually a gas-fired condensing boiler at £2500 installed cost) - are evaluated based on the difference in total installed cost between the microgeneration system and the conventional alternative; these technologies are indicated by italic typeface in Table 1 . Carbon dioxide savings for micro-CHP reported here are based on authors' estimates, ${ }^{27,28}$ generally supported by results of the Carbon Trust's micro-CHP field trial. ${ }^{29}$ When interpreting Table 1 it is important to note that reported simple payback periods are with respect to the capital cost after government support has been taken into account. It is therefore an estimate of the payback seen by the potential owner-operator, which is shorter than normal payback periods. It should be noted that all data presented in Table 1 are subject to the specific stated assumptions, and wide variations are apparent in terms of performance of technologies and energy consumption in individual dwellings. The information presented is indicative only.

Two clear conclusions may be drawn from Table 1. First, it is obvious that the combination of policy instruments is supporting a wide range of carbon prices. This range is due to the LCBP and VAT relief. The LCBP is therefore not a measure specifically directed at achieving carbon dioxide emissions reduction, but is more a platform to raise the profile of the technologies and kickstart the market. Likewise, VAT relief is indiscriminate in terms of support for carbon dioxide reduction, providing 12\% capital cost reduction regardless of performance. It could be argued that the LCBP is more directed than VAT relief, as the LCBP process represents a form of vetting of applications (external benefits are gained through LCBP in that in order to be eligible for support a dwelling must be well insulated, install quality heating controls and efficient lighting). The second conclusion to be drawn from Table 1 is that microgeneration systems that are home heating solutions can benefit greatly from support, with payback times to the supported owner-operator of only a few years for near-tomedium-term micro-CHP technology.

The CERT is a much more carbon dioxide savings oriented mechanism, providing a fixed reduction target and flexibility on how to meet it. In the sense that qualifying actions compete with one another, the CERT should provide an economically efficient overall solution. Possibly the biggest deficiency in the CERT is that carbon dioxide savings are measured with respect to a businessas-usual scenario and therefore do not necessarily provide an absolute carbon dioxide reduction. There is no simple solution to 


\begin{tabular}{|c|c|c|c|c|c|c|c|c|}
\hline Technology & $\begin{array}{l}\text { Estimated } \\
\text { total } \\
\text { installed } \\
\text { cost, } \\
\text { including } \\
\text { VAT at } \\
5 \%: ~ \\
\text { 5 }\end{array}$ & $\begin{array}{l}\text { Estimated } \\
\text { LCBP } \\
\text { grant } \\
\text { support: } £\end{array}$ & $\begin{array}{c}\text { Estimated } \\
\text { CERT } \\
\text { support } \\
\text { assuming } \\
£ 20 / \mathrm{tCO} \\
\text { value to } \\
\text { supplier: } €\end{array}$ & $\begin{array}{c}\text { VAT } \\
\text { reduction } \\
\text { from } 17 \cdot 5 \\
\text { to } 5 \%: £\end{array}$ & $\begin{array}{c}\text { Total } \\
\text { public } \\
\text { support: } t\end{array}$ & $\begin{array}{l}\text { Estimated } \\
\text { lifetime } \\
\text { carbon } \\
\text { dioxide } \\
\text { emissions } \\
\text { reduction: } \\
\mathrm{tCO}_{2}\end{array}$ & $\begin{array}{l}\text { Public cost } \\
\text { of carbon } \\
\text { dioxide } \\
\text { saved: } \\
\epsilon / \mathrm{tCO} \\
\end{array}$ & $\begin{array}{l}\text { Simple payback } \\
\text { period for } \\
\text { owner- } \\
\text { operator with } \\
\text { government } \\
\text { support: years }\end{array}$ \\
\hline I kWe solar PV* & 5500 & 2000 & 240 & 714 & 2914 & 9 & 329 & 58 \\
\hline I kWe micro-wind ${ }^{\dagger}$ & 1800 & 540 & 140 & 214 & 834 & 7 & 128 & 18 \\
\hline $\mathrm{GSHP}^{\ddagger}$ & 10000 & 1200 & 720 & 1190 & 3110 & 36 & 86 & 56 \\
\hline Biomass boiler $\S$ & 10000 & 1500 & 1520 & 1190 & 4210 & 16 & 55 & $8-\infty 9$ \\
\hline Low-HPR ${ }^{* *}$ micro-CHP & 4000 & $500^{\dagger \dagger}$ & $200^{\dagger \dagger}$ & 476 & 1176 & $10^{\dagger \dagger}$ & 118 & 5 \\
\hline High-HPR ${ }^{* *}$ micro-CHP & $3500^{\dagger \dagger}$ & $500^{\dagger \dagger}$ & $100^{\dagger \dagger}$ & 417 & 1017 & $5^{\dagger \dagger}$ & 203 & 4 \\
\hline Solar hot water & 3200 & 400 & 160 & 381 & 941 & 8 & 118 & 53 \\
\hline \multicolumn{9}{|c|}{ 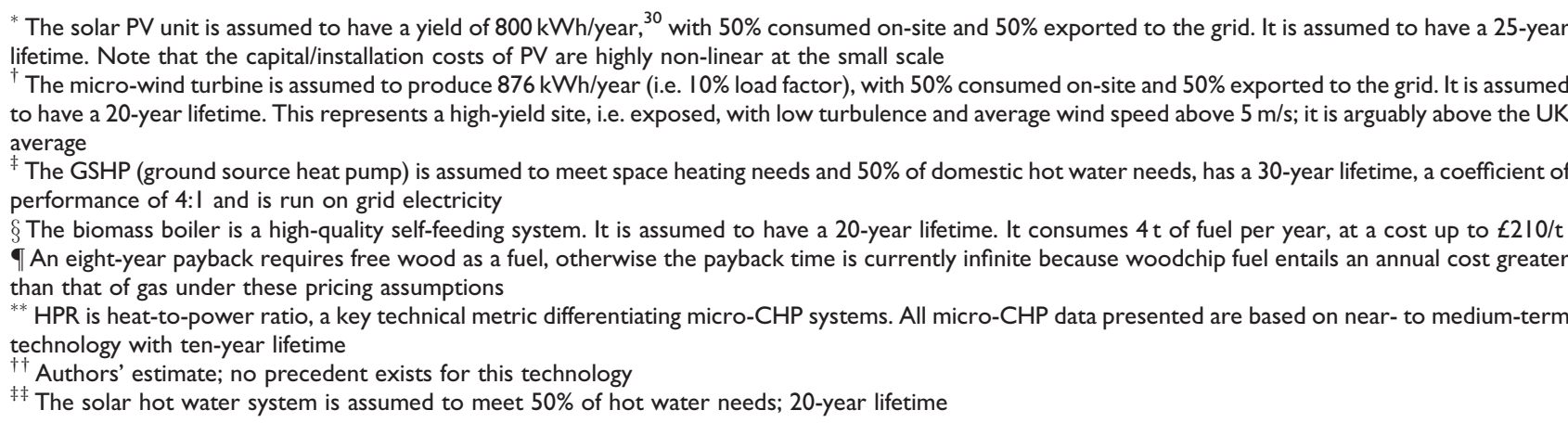 } \\
\hline \multicolumn{9}{|c|}{$\begin{array}{l}\text { Table I. Total societal cost of policy instruments for key microgeneration technologies. All economic estimates made using a current } \\
\text { residential energy tariff offered by a major supplier, for energy consumption corresponding to a UK median dwelling. Exported electricity is } \\
\text { assumed to attract } 4 \mathrm{p} / \mathrm{kWh} \text { payment. All carbon calculations based on assumed embodied carbon dioxide of } 0.43 \mathrm{~kg} / \mathrm{kWh} \text { for electricity } \\
\text { and } 0.19 \mathrm{~kg} / \mathrm{kWh} \text { for gas. Payback is calculated assuming } 0 \% \text { cost of capital and zero operating expenses. It is recognised that all results are } \\
\text { estimates and substantial variation exists from installation to installation. Both CERT support and VAT reduction are notional amounts. The } \\
\text { level of CERT support provided by a supplier is dependent on a business offering and therefore challenging to quantify. VAT reduction is } \\
\text { not seen by the owner-operator; it is an avoided expense rather than cash support }\end{array}$} \\
\hline
\end{tabular}

this problem and there is no simple way to measure absolute reduction at the individual residential level. Most possibilities involve metering dwellings benefiting from an action, and adjusting readings for a variety of factors that are difficult to quantify (average temperature, seasonal, behavioural, etc.). Nevertheless, the development of a cap-and-trade system similar to CERT but which provides absolute emissions reduction is an interesting possibility for future policy direction.

At the other end of the policy spectrum are minimum standards regulations such as building regulations and local planning policies. At country-level, the proposed direction for building regulations (e.g. the code for sustainable homes) is a powerful tool that could effectively mandate the introduction of substantial microgeneration. The details of implementation of such policies require careful consideration. For example, the current

assumption within the SAP is that microgeneration benefits from a higher displaced carbon dioxide rate than on-site consumption. Indeed, the current distinction between a zero DER as calculated by the SAP and 'truly zero-carbon' level 6 of the code for sustainable homes requires attention.

The final point regarding regulation relates to local versus national approaches and the need to link them effectively. Devolved approaches appear to be a powerful tool for realising national direction, and clear distinction of the roles of local, regional and national policy and regulation could aid certainty in the microgeneration industry.
Perhaps the primary question regarding how these policy instruments relate to microgeneration is 'how predictable are the carbon dioxide savings for each technology?' Any carbon dioxide saving item, including energy-efficiency measures, has some uncertainty with respect to actual carbon dioxide savings. For example, savings attributable to cavity wall insulation are roughly dependent on the annual thermal demand of the dwelling, but are also influenced by other factors such as the behaviour of the owners. Likewise, as suggested by the interim results of the Carbon Trust's micro-CHP field trial ${ }^{29}$ and a variety of published modelling studies, carbon dioxide savings from micro-CHP technology are correlated with annual thermal demand. In the past, EECs have attributed average savings to each measure, relying on a large number of installations to provide the correct aggregate savings. This assumption could still function reasonably well when microgeneration is added to the list of supported measures, but nonetheless probably does not provide the optimum carbon dioxide savings for the given public or private investment. Suppliers might be better encouraged to incentivise effective investment if they were required to estimate carbon dioxide savings and meet a certain standard before providing support, although such an approach could be overly onerous.

All of the issues discussed above serve to highlight that while progress has been made regarding policy and regulation for microgeneration (and related actions), there is great potential for developing further understanding and approaches. Current microgeneration policy is focused on uptake of systems and does 
not pay sufficient attention to how consumers behave after installation. These behavioural aspects are discussed in more detail in the next section, highlighting that the interconnection between policy mechanisms and behaviour is key if policy goals are to be met through microgeneration. This interconnect is not well understood and would benefit from further research incorporating technical understanding, policy development and behavioural sciences. A suite of policy instruments to deliver reliable near-term carbon dioxide savings at low public and private cost needs to be developed to specifically address the unique aspects of the residential sector. Looking further into the future, the potential to completely decarbonise residential heating should be addressed, and should include the creation of an understanding of path dependency (i.e. the possibility of suboptimal lock-in) and associated policy. This is particularly true of standards and policy related to zero-carbon buildings and implementation of the Merton rule.

\section{BEHAVIOURAL ASPECTS}

Maximising energy and emissions savings via microgeneration requires both significant uptake of the technology among consumers and behavioural changes in domestic energy use. As discussed earlier, much existing policy focuses on uptake only, which may not encourage appropriate behavioural changes. This section puts microgeneration in the context of energy-related behaviour and the broader social and infrastructural measures that could shift domestic energy use to more sustainable patterns. Consideration of these issues in policy instrument formulation could enable policy aims to be achieved.

\section{I. Behaviour and behaviour change}

Energy-related behaviour is often thought of simply as 'consumption'. However, consumption is not just about satisfying needs, but is connected to identity and meaning creation; material goods play symbolic roles in our lives beyond their functional uses. Specifically, environmentally significant (consumer) behaviour is culturally embedded and includes social, moral and normative considerations. ${ }^{31}$

There is a distinction between routine behaviour, which is repetitive and can become habitual and therefore reduces rational, conscious deliberation in a 'behavioural lock-in', and deliberative behaviour, which is used for larger, less frequent choices. Rational actor type models are not appropriate for the first behaviour type, but have some merit in the second. ${ }^{31}$ Routine behaviour, and potential changes to it, might apply to behaviour before and after installation of microgeneration or other energy-saving methods. In this context, Stern ${ }^{32}$ found that 'many environmentally significant behaviours are matters of personal habit or household routine and are rarely considered at all'. Deliberative behaviour is more useful in questions of purchasing or installing microgeneration units. For example, installing a PV system is an important decision that may be taken only once in a person's life; its evaluation includes not only subsistence and comfort but also identity, freedom, 'belongingness' and more. ${ }^{33}$

People generally see government as responsible for addressing environmental problems and expect government (or industry) to take the initiative; they see themselves as having little effect, or prime responsibility for these problems. This disempowerment, rather than ownership, includes energy production, usage, efficiency and needs. ${ }^{31,34,35}$ There is a lack of connection between personal behaviour and global consequences, as well as a lack of understanding of the impacts of individual behaviour on energy usage and carbon dioxide emissions/global warming. This supports the idea that pro-environmental behavioural change can be thought of as a transition in social norms, and therefore behaviour change must occur at the collective, social level: 'individual change is neither feasible nor sufficient'. ${ }^{31}$ This implies that change is required in the way the public view electricity generation and distribution if microgeneration is not only to spread but also to include the accompanying behaviour changes needed to maximise its benefits. Social networks are also important - people's choices can be strongly affected by friends, family and celebrities/role models. Applying these ideas to microgeneration implies two things.

(a) In order to maximise energy and carbon emission reductions, institutional and cultural changes are needed beyond just persuading individuals to install microgeneration units. Public acceptance of renewables in many countries has misled policymakers to believe that social acceptance - be it local installations or willingness to invest in microgeneration would not be a problem. ${ }^{36}$ However, microgeneration requires 'active' acceptance on the part of the public as compared with 'passive' consent, which is sufficient for large infrastructure projects. ${ }^{35}$ This includes community acceptance for specific sites and market acceptance for people to invest (unlike 'green energy' which requires no actual involvement). Further, market adoption can be separated from broader social acceptance. $^{36}$

(b) Without cultural and behavioural changes, maximising installations might not in itself yield maximum potential savings. As Keirstead puts it 'there is a danger that if behavioural responses to microgeneration technologies are not considered now, when consumer technologies and protocols are still being developed, then the industry could find that households become locked into behaviours that may be undesirable in the longer term, ${ }^{37}$ In other words, 'it would be naive to think of microgeneration simply as another generation technology'. ${ }^{38}$

Policy has to come to terms with these contexts if it is to influence individual behaviour; information on its own is unlikely to be effective against powerful influences such as social norms and prices, and mixed messages can lead to resentment. ${ }^{31,34}$ The government must also contend with low levels of trust and perceptions of lack of fairness in key actors; these factors have been identified as influential in previous opposition to renewable energy, affecting how information is received by the public. ${ }^{39}$ Stern advises using different combinations of policy measures to change routine behaviour until the most effective combination is found. ${ }^{32}$ The UK Department of Trade and Industry (DTI) - now known as the Department for Business, Enterprise and Regulatory Reform (BERR) - microgeneration strategy ${ }^{10}$ looks at top-down community installations, and in what appears to be politics of aspiration declares that 'An attractive community installation can familiarise local residents with microgeneration technologies, demonstrate the potential for home generation and maybe even encourage people to change their own behaviour to be more energy efficient'. ${ }^{40}$

\subsection{Systemic change}

Research into the diffusion of innovation often describes the uptake of new technologies as a process with adopters classified in 


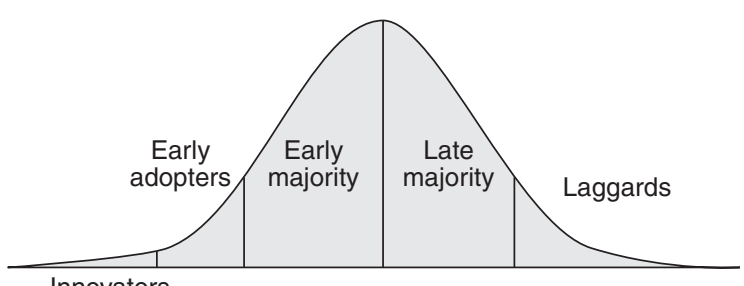

Innovators

Figure I. The five categories of innovativeness ${ }^{41}$

categories of innovators, early adopters, early majority, late majority and laggards (see Figure $1^{41}$ ). Innovators and early adopters put more weight on personal motivations, which could include saving money, love of technology and self-sufficiency, while the majority of later adopters put more weight on social motivations, which could include social status of the technology and friends and relatives who have purchased it. ${ }^{41}$ The former are willing to pay more money and take bigger risks when buying a new technology, while for the latter, purchase requires a lower price (or shorter payback time) and a good reputation. Uptake by innovators and early adopters therefore does not guarantee success in diffusion to the greater public. The necessary leap of microgeneration from early adopters to the majority, if it is to become a major part of the UK energy system, must take these lessons into account.

The need for institutional, behavioural and cultural change, as well as the notion of lock-in are all present in transitions theory. This stipulates that persistent problems (such as reduction in household energy use or carbon dioxide emissions), which include social, institutional and structural issues, cannot be solved by topdown incremental changes alone, but instead require radical, systemic change over years or decades. Transition theory warns against focusing on system optimisation rather than system innovation. ${ }^{42,43}$ Such a transition may be catalysed by new functionalities or behaviour associated with a new technology. These can affect uptake as demand for the new functionality itself emerges, as opposed to the demand for the technology that introduced it. ${ }^{43}$ For example, mobile phones precipitated changes in behaviour, such as blurring boundaries between work and social life, private and public life, and introduced new functionalities, such as quick text, photo messaging on the move and availability of communication, which themselves have become sought after. ${ }^{44} \mathrm{New}$ functionalities in the microgeneration context could include on the one hand concepts of households as 'energy co-providers ${ }^{45}$ or "energy citizens ${ }^{46}$ and, on the other, easily available information on energy usage, production, export and price through new metering options.

The new functionalities of microgeneration could potentially be a disruptive innovation to the current conventional central generation of electricity and home-generated heat via boilers. Disruptive technology introduces a new value proposition that might create a new market or reshape the existing market. ${ }^{47,48} \mathrm{~A}$ shift to generation of electricity and possibly production of heat via the range of available microgeneration technologies will alter the shape of the electricity and gas markets, which in turn will affect not only consumers but also larger market players such as suppliers, generators and market operators. Although microgeneration might not necessarily be very efficient compared with larger electricity-producing devices in power plants, taking losses in the network into account makes microgeneration viable as it increases overall efficiency and potentially reduces customers' energy bills. It thus becomes a desirable option for residential customers who might displace a portion of conventional generation.

The current lock-in is evident in that 'technical infrastructure and social norms interact to affect behaviour over time. Both may be resistant to change'. ${ }^{34}$ However, the current focus is on incremental change, not systemic shift. Watson et al. believe that 'current policy is too focused on incremental changes. It misses opportunities to support micro-generation as part of a broader shift towards demand reduction and consumer behaviour change' ${ }^{38}$ For example, uncertainty surrounding grants leads installers to focus on maximising sales. They might not be aware of their ability to influence consumers' behaviour, and this limited interaction reduces energy-saving possibilities; reaping the full benefits requires a supportive socio-technical system to be in place. ${ }^{37}$ Another way to express this missed opportunity is the difference between an 'energy consumer' scenario and an 'energy citizen' scenario ${ }^{49}$ (Table 2). At present (business-as-usual), people are both consumers and citizens, but business and industry focus on the former. In the microgeneration context, this focus encourages hard sales to maximise uptake, but not environmental benefit, leading to the microgeneration/consumer scenario. However, a shift to focusing on energy citizenship could encourage wise use and greater energy savings, leading to the microgeneration/citizen scenario.

\subsection{Motivations and barriers}

There are various motivations and barriers, some more rational than others, in the decision to purchase microgeneration. The 'rational' motivations most often listed are economic, environmental, technological interest and self-sufficiency, ${ }^{50,51}$ with other motivations including familiarity of technologies, social acceptance and more.

3.3.1. Cost. The economics of microgeneration - up-front cost, payback times and potential long-term savings - are an important consideration in the decision if and what to buy. The up-front price of microgeneration is still a real barrier to many and, without subsidies, large parts of the population would be excluded. .3,52,53 $^{3}$ Payback times can be very long. For example, for a PV system, some estimates are 30 years, ${ }^{33}$ although the current study approximated a period closer to 60 years (see Table 1); this is similar to the life expectancy of the unit, or even longer. Subsidies, grants and innovative tariffs can shorten payback times for consumers.

\begin{tabular}{|c|c|c|}
\hline Scenario & Energy consumer & Energy citizen \\
\hline Business-as-usual & $\begin{array}{l}\text { Economic rights } \\
\text { (and social } \\
\text { opportunities) }\end{array}$ & $\begin{array}{l}\text { Political rights } \\
\text { - voting } \\
\text { - earning } \\
\text { - responsibilities }\end{array}$ \\
\hline Microgeneration & $\begin{array}{l}\text { Buy more } \\
\text { microgeneration } \rightarrow \\
\text { smart houses, } \\
\text { passive users }\end{array}$ & $\begin{array}{l}\text { Wise use and } \\
\text { sufficiency } \rightarrow \text { smart } \\
\text { houses, smart users }\end{array}$ \\
\hline
\end{tabular}


The cost barrier is crucial, as financial motivations commonly underpin energy conservation. While environmental values and concerns may increase people's willingness to conserve energy, they are considered alongside perceived costs and benefits. ${ }^{54}$ It is also worth noting that the perception of costs is sometimes inaccurate. For example, in a study of attitudes towards rooftop microgeneration, over 50\% of Londoners surveyed thought it would be too expensive to install. However, solar thermal prices were overestimated and PV prices underestimated; cavity wall insulation prices were also overestimated. ${ }^{55}$

A variety of ideas for help with costs are available, for example

(a) including installation costs with mortgages (especially for new houses) since people make long-term calculations when buying property ${ }^{33}$

(b) installing microgeneration in social housing

(c) providing clear guidance on ROCs and other schemes

(d) reducing VAT and including microgeneration technologies in the CERT (see also Section 2.2.2)

(e) rewarding electricity export. ${ }^{40}$

However, Sauter and Watson ${ }^{35}$ question the notion of consumers as rational economic agents - specifically, the notion that households will only invest in microgeneration if the payback time is in the range of a few years. Most households in the UK do not invest in energy-saving measures that are proven to have such a payback time (e.g. cavity wall insulation), while more invest in double glazing, which has a much longer payback time. This is probably a result of both the images of the two technologies, including familiarity with double glazing and its visibility, and additional immediate benefits of double glazing, most notably noise reduction. People tend to discount or devalue delayed outcomes; they generally do not consider future savings or revenues from energy. ${ }^{33,53}$ The dilemma between short-term negative outcome and long-term positive outcome can cause cognitive dissonance; people tend to discard long-term benefits for reasons such as high cost, excessive bureaucracy, minute contribution to the environment, and so on. ${ }^{33}$

3.3.2. Export tariffs. An important part of cost considerations are export tariffs for producing and exporting electricity, which can be an important incentive to both installation and efficient use. There are limited customer-facing drivers and even early adopters are only willing to pay a modest premium for new technology. ${ }^{29}$

Not all consumers are paid for their exports and (until recently) tariffs were not high enough to influence consumer behaviour. ${ }^{29,37}$ Ofgem has made it compulsory for suppliers to quote a buyback price for customers selling electricity to the grid.
The value of microgeneration to the supplier varies according to the type of generation (predictable or intermittent) and, more importantly, how much is actually exported into the grid. ${ }^{56}$ The export reward can consist of a fixed lump-sum payment (usually for unmetered generation) or variable payments (usually for metered generation). Currently, retailers offer tariffs of 4.25-18 p/kWh for metered generation, depending on a variety of factors including supplier, region, type of generator and type of residence. ${ }^{56}$ Unmetered reward for export is currently valued at around $£ 10$ per year on the EDF green tariff scheme and £18 per year on British Gas ecosave; energy supplier e.on estimates a lump sum payment based on characteristics of customers' consumption patterns. ${ }^{56}$ Higher export rewards offer an improvement for consumers and incentives for manufacturers to improve electrical efficiency. However, incentives must avoid supporting excess heat generation and dumping for electricity rewards. In any case, tariffs are expected to be lower than retail price. ${ }^{29}$ The government is pushing to reward renewable microgeneration with two ROCs per MWh ( $\sim 9 \mathrm{p} / \mathrm{kWh})$ and this is aimed to start in April 2009. ${ }^{56}$ For Stirling engines (and assumed prices), the Carbon Trust found no commercial benefit for domestic users without payment for electricity export.

More recently, several companies in the UK have started offering tariffs with better incentives for consumers. For example, Good Energy requires installation of a generated electricity meter and pays a flat tariff for generated electricity with no reward for export. ${ }^{57}$ Equipower installs free export meters for its customers and pays different tariffs for generation and export of PV and wind turbine energy. ${ }^{58}$ Both companies offer customers incentives for microgeneration. The Good Energy scheme and the Equipower wind tariff create an incentive to maximise energy use on-site as this maximises the reward: the tariff is received and bills for grid electricity are reduced. Equipower PV gives a larger incentive for export (Table 3). Ofgem recommends regulating feed-in tariffs for microgeneration export to the grid. ${ }^{59}$ This would force grid operators to allow access to exported energy. Export price would be fixed, although it might vary between technologies. Feed-in tariffs are already used in some European Union countries to encourage renewable energy development and have proved successful in Germany, Spain and Denmark. In Germany, the '100 000 rooftop programme' resulted in significant growth in PV instalments from 1999, but it was the introduction of fixed-rate tariffs per kWh generated that enabled a real market take-off, as well as creating thousands of jobs. ${ }^{60}$ Tariffs must be high enough to encourage the market, but if they are too high they could ultimately stifle investment. ${ }^{61}$

Under the microgeneration strategy ${ }^{10}$ launched in 2006, suppliers were encouraged to offer export rewards to domestic customers

\begin{tabular}{|c|c|c|c|c|}
\hline Supplier & $\begin{array}{l}\text { Tariff for generated } \\
\text { electricity: } \\
\text { p/kWh }\end{array}$ & $\begin{array}{c}\text { Additional tariff for } \\
\text { exported electricity: } \\
\mathrm{p} / \mathrm{kWh}\end{array}$ & $\begin{array}{c}\text { Savings for on-site use } \\
\text { of generated electricity: } \\
\text { p/kWh }\end{array}$ & $\begin{array}{c}\text { Savings from } \\
\text { exported electricity: } \\
\mathrm{p} / \mathrm{kWh}\end{array}$ \\
\hline Good Energy ${ }^{57}$ & 9 & 0 & 21 & 9 \\
\hline EBICo Equipower PV ${ }^{58}$ & 0 & 18 & 12 & 18 \\
\hline EBICo Equipower wind ${ }^{58}$ & 5 & 5 & 17 & 10 \\
\hline
\end{tabular}


with microgenerators. In general, these tariffs might encourage an increased uptake of microgeneration as well as appropriate application of microgeneration. For example, if suppliers incentivise export of electricity produced by solar, customers might install more PV panels. However, this type of technologybased rewards system should be analysed carefully - customers need to know whether the payback time for their investment is economical.

Ofgem has recently introduced a requirement for suppliers to be more transparent in reporting their portfolios for green tariffs. ${ }^{56}$ Hopefully this will allow renewable microgeneration to be included in the same portfolio, giving suppliers a higher percentage of green energy production and at the same time rewarding owners of microgenerators. Increasing electricity and gas prices as well as the existence of proper incentives for microgeneration could make the adoption of renewable microgeneration rewarding. For micro-CHP the situation is more complicated: economic viability depends largely on the existence of a considerable gap between electricity and gas prices and the export reward might therefore be unsustainable over time. Moreover, the emissions savings of natural-gas-powered CHP depend on the carbon dioxide intensity of the grid.

\subsubsection{Environmental awareness. A 2006 in-depth study on} renewable energy of over 6000 UK consumers ${ }^{51}$ found strong support for renewable energy: 68\% stated they would like their electricity to be derived from renewables, 44\% from large-scale and 24\% from microgeneration. The most common motive for supporting renewables was reported to be preventing climate change (44\%), with saving energy costs (24\%) and self-sufficiency $(22 \%)$ also important. Although this shows that there is environmental awareness, there is still little conscious awareness among most consumers that 'lights, heating and appliances within the home are running off fossil fuels extracted from the earth and sea, let alone that a by-product of their usage is carbon emissions which are the key drivers behind climate change'. ${ }^{62}$ Furthermore, as mentioned earlier, environmental motivations are commonly underpinned by financial motivations ${ }^{54}$ and thus may not be enough to catalyse action on their own. Therefore, while continuing to raise environmental awareness, specifically about the connection of household behaviour with climate change, is necessary for domestic emission reductions, it is not sufficient.

\subsubsection{Technology as motivation and barrier. An interest in} technology is important among innovators and early adopters. For example, Haas et al. ${ }^{50}$ found that participants in PV trials in Austria were typical innovators, 'technically interested and ready for financial risk'. A German study ${ }^{63}$ found that those interested in participating in trials of domestic fuel cell CHP had more interest in new technology, higher technical education (compared with the general public) and a belief that technologies could solve environmental problems. In the UK, installation of microgeneration is most likely to be environmentally motivated, although some are motivated through love of technology. ${ }^{62}$

Jager $^{33}$ found that among trial PV installers in the Netherlands, technical support offered by the municipality was the lowest of seven motivations for installation and, in sharp contrast to the UK, most people in the sample installed the PVs themselves. This fits the profile of innovators, but also has to do with regulation differences between the two countries.
Most of the population has a less innovative attitude than innovators and early adopters and the prevalent perception that some technologies are immature or unreliable can be a major barrier to purchase. ${ }^{34,35}$ Making matters worse, there is a problem of lack of technical expertise. For example, there is a lack of installation and maintenance skills for domestic CHPs, which could result in inappropriate installation or inefficient use, and failures in commercial CHPs or domestic PV systems can go unnoticed for a long time without expertise for assessing performance. ${ }^{29,64}$ However, the fact that there are similar problems with conventional heating systems ${ }^{33}$ supports the idea that there is a need for a cultural shift if the demanding energy and emission reductions of $80 \%$ are to be achieved in general, and if this young technology is to succeed in particular.

3.3.5. Familiarity and habit. Familiarity and habit also play a part in decision making. The Energy Saving Trust ${ }^{65}$ models familiarity as a simple function of overall installed units in the UK. This is consistent with studies such as that undertaken by London Renewables, ${ }^{66}$ which found that while a vast majority were in favour of renewable energy, solar and wind were more likely to be supported than CHP, incineration or anaerobic digestion; the negative view of the latter technologies could be related to lack of knowledge about them. However, some studies show the importance of personal history and experience or the 'exposure effect'. For example, Allegra Strategies ${ }^{51}$ interviews indicated people who 'only know' gas, oil or coal, and don't wish to try anything new; most of these respondents were aged 55 or over. Other aspects of familiarity include the 'observability effect', notably of PV systems, which could aid diffusion, and the lack of 'trialability' of PV (and other microgeneration) systems, meaning the system cannot be tried before installation. $^{33}$

\subsubsection{Social motivations. Beyond familiarity, networks of} friends and acquaintances could play an important role in the significant and complex decision of microgeneration. Jager ${ }^{33}$ found that social motivations for installing a PV system were strong among the socially informed, who tended to know more people with PV. He suggests that for the general population, social effects could be more important than for early adopters, with a potential role for role models and viral marketing. This is in line with diffusion of innovation. ${ }^{41}$

Social motivations also include the social status connected with environmentally aware behaviour. Green consumerism relies on the fact that consumption is partially motivated by the social status purchased products might confer, and attempts to attach higher status to environmentally-friendly products. However, it is not clear that this will contribute to reducing environmental problems. ${ }^{67}$ If the social motivation is dominant, there is a push for visible action over environmentally effective action. A prime example, if anecdotal, comes from a BBC radio interview in 2007 (transcript cited in Crompton ${ }^{67}$ ) '... One of my friends has got a solar panel on the north-facing roof of her house. When I pointed out to her that's not necessarily the best place in the UK in order to be generating energy, she pointed out to me that I wasn't understanding why she'd done it. The north-facing part of her house is the part that faces the street'. Social (and other non-environmental) motivations for installing microgeneration also risk increased energy use through the rebound effect (see Section 3.5). 


\subsection{Information and choice of technology}

3.4.1. Information and promotion. The BERR (formerly the DTI) recommends: overcoming information constraints by producing information for the construction industry and (separately) for local authorities; developing a comprehensive accreditation scheme; and information campaigns for consumers to fill information gaps and raise the profile of microgeneration. ${ }^{40,68}$ However, this does not address the limitations to information supply alone, and Devine-Wright ${ }^{39}$ warns against assuming people have a clear idea about the carbon emissions of different technologies; for example, some people believe natural gas is 'renewable' compared with low awareness of 'biomass'. Nor does it address the issue of low levels of trust in public actors ${ }^{39}$ and 'it is crucial that microgeneration does not earn a bad image because of mis-selling and bullying sales tactics' ${ }^{69}$

Jager $^{33}$ reports on a PV diffusion exercise in the Netherlands following high subsidies in 2001-2003, and specifically on promotional campaigns in the city of Groningen. Although the media considered the scheme a success, from a strictly economic perspective the uptake was modest considering the 90\% subsidy, which reduced break-even time to three years. In Groningen, the municipality promoted the scheme through newspaper advertisements and special information meetings on PV systems to address technical and bureaucratic barriers, but the grants were the same as nationally. Some 113 out of 188 (60\%) interviewees attended at least one meeting. The meetings slightly reduced the perceived bureaucratic and technical installation barriers, although neither was seen as a very difficult barrier beforehand. Nonetheless, the uptake in Groningen was about ten times the Dutch average. While this undoubtedly points to a successful campaign, even in Groningen those who took up the offer had a higher awareness of environmental problems than the general population, which would imply that they were still early adopters.

In the UK, television is one of the main sources of information about renewable energy, with newspapers playing an important part in rural areas. As customers deal with suppliers directly, suppliers can be a source of information on renewable energy and available microgeneration options. Direct experience, such as visiting wind farms, is also important. ${ }^{39}$

\subsubsection{What determines choice of technology? Microgeneration} refers to a basket of technologies, some of which use renewable sources and some of which offer energy efficiency even if they use fossil fuels. Behaviour and attitudes may therefore be technology specific and choosing what to install has to do with the aforementioned motivations of cost and environmental effect. BERR proposes to develop a 'route map' for each technology, ${ }^{40}$ which could help determine targets and criteria for the most appropriate technology in different households. However, information may be lacking: people do not always know the costs, carbon emissions and other parameters of different technologies, ${ }^{39}$ making reputation and familiarity important.

This can lead to the emergence of a dominant design in each microgeneration category or even one microgeneration type. A technology that is first to be marketed or is the one being chosen by a majority of consumers could go on to be the dominant technology due to familiarity and ease of access. This in turn yields more resources to develop it further, hence accelerating its development. As Suarez and Utterback ${ }^{70}$ claimed, 'a dominant design has the effect of enforcing standardization so that production economies can be sought'. However, the problem with this emergence is that the chosen technology might not necessarily be the best in terms of technical performance and cost. For example, if the WhisperGen $^{71}$ Stirling engine micro-CHP unit is ready to be marketed first, the company would continue to develop a supply chain and build a customer base. The reduced market size and locked-in Whispergen customers then make it difficult for another producer to penetrate the market in the future. Home information packs (HIPs), which list energy-saving measures in order of the potential carbon dioxide emissions saved, are beginning to address this.

People relate to specific technologies more than the broad term 'renewables'; wind, solar and hydro-power are the most recognised, compared with biomass which is less well known. Wind and solar have 'iconic' value as renewable sources; while solar is the most positively regarded, wind farms are the most socially contentious. ${ }^{39}$ In one survey, most Londoners questioned were found to be aware of solar and wind power, and felt they knew at least something about them (with solar thermal and PV better known than micro-wind), ${ }^{55,66}$ but information gaps exist around practical information such as cost, how the technologies are installed and who installs them. In contrast, other technologies (including CHP) are less well known, poorly understood and were not intuitively considered 'renewable' in the same way as the former. Ellison ${ }^{55}$ found that approximately $21 \%$ of a sample were 'very likely' or 'fairly likely' to install PV or solar thermal, compared with $6 \%$ for micro-wind.

The Welsh Consumer Council ${ }^{69}$ reports that solar-thermal technologies sometimes have a sales reputation problem, with some companies implicated in aggressive sales tactics and inflated prices. The council warns 'the greater the risk of people being missold unsuitable systems, the greater the risk to microgeneration's public reputation'. ${ }^{69}$ Other, newer technologies tend to be better regulated and are less likely to fall into disrepute. However, sales tactics such as unrealistically low payback times advertised by manufacturers for some microgeneration installations ${ }^{72}$ could also potentially harm microgeneration's reputation. This highlights the importance of consumers' access to independent advisors. Caird et al. ${ }^{73}$ found that most people 'accepted the recommendation of [solar thermal] installers, usually without understanding the technology'. Installers' opinions may be crucial. Many people who considered microgeneration but rejected it did so because of uncertainty about new technology. Some $43 \%$ of people stated that reputation for unreliability was a barrier to purchasing a condensing boiler - a reputation that persisted until installation of such boilers became virtually mandatory under UK building regulations in $2005 .^{73}$

\subsubsection{Who currently purchases microgeneration? Those} installing microgeneration in the UK match Rogers' description of innovators and early adopters ${ }^{41}$ and their socio-economic profile is different from that of the general population. Studies of PV adopters in the $\mathrm{UK}^{37}$ and the Netherlands ${ }^{33}$ found they were older than the average population, better educated, had a higher environmental awareness, were wealthier and more likely to own their own home. Reviewing different studies, Devine-Wright ${ }^{39}$ found 
(a) that older people were more aware of microgeneration, but younger people were more likely to install it

(b) contradictory results as to the gender effect

(c) that people with higher income and in higher social classes had more support for renewables in general, but limited evidence that more informed individuals are more accepting of low-carbon technologies

(d) a clear correlation between political beliefs and acceptance of microgeneration (with Conservatives less accepting than Liberal Democrat or Labour supporters in the UK).

People investing in microgeneration had often implemented other energy-saving measures, such as cavity wall insulation, efficient lighting and solar thermal installation, before installing PV. ${ }^{37,50}$ In other words, PV installation was the last part (so far) in an energy conservation chain that might continue with other measures after installation.

\subsection{Behaviour change after purchase/installation}

Results are ambiguous as to whether installing microgeneration technologies (or moving into a house already fitted with microgeneration) will in itself cause behaviour change. ${ }^{35}$ However, Dobbyn and Thomas ${ }^{62}$ show evidence of awareness, behaviour and attitudinal shifts for most people interviewed after gaining microgeneration. This was true for both active (i.e. choosing to install) and passive (living in a house with microgeneration) households, with even modest amounts of energy production having significant behaviour impacts. Living with microgeneration technology encouraged a greater understanding of energy issues, often impacting on behaviour. Households motivated through a love of technology or selfsufficiency exhibited a greater shift in behaviour than environmentally motivated households, which already had a 'green' lifestyle. However, the mere presence of technology did not always cause this shift, with many passive households exhibiting a 'love of the newfound warmth and comfort of their home', ${ }^{62}$ without necessarily reducing energy consumption. Changes to routine behaviour were observed, such as avoiding turning lights and fires on, switching appliances off at the mains and using washing machines at peak production periods. This is in contrast to mainstream routine behaviour, which shows few attempts to reduce consumption and little conscious awareness of the fact that the fossil fuels are burned for lighting, heating and powering appliances. A better understanding of this type of behaviour change, specifically under what conditions it occurs, is vital to maximising the energy-saving potential of microgeneration.

The PV installation experiment in Austria revealed that households with high initial electricity consumption tended to reduce their electricity usage, while those with a low initial consumption tended to increase their usage. ${ }^{50} \mathrm{PV}$ may thus be an 'energy conservation tool for the rich, ${ }^{50}$ Keirstead $^{37}$ found two significant differences after PV installation: an increase in use of green electricity tariffs and the use of efficient lighting. People reported that they were more likely to undertake efficiency improvements to lighting and appliances, and were slightly more likely to install other microgeneration. Keirstead also reports a self-assessed overall saving of 5.6\% in energy consumption, largely the result of higher awareness of electricity generation and consumption issues. However, it is difficult to determine whether these were temporary or long-lasting changes.
The increased use of energy after installing microgeneration is an example of the rebound effect. ${ }^{74}$ The cheaper energy provided may encourage consumers to use more energy, for example by keeping the home warmer (direct rebound), or the money saved from lower energy bills may be used on energy-intensive goods and services (indirect rebound). Both cases reduce overall energy and emission savings.

\subsection{The importance of meters and feedback}

Clear feedback is a necessary part of energy demand reduction, including both instantaneous clear direct feedback, which could be from smart meters or other monitors, and frequent accurate billing (indirect feedback). ${ }^{75}$ Savings can reach 5-15\% from direct feedback and $0-10 \%$ from indirect feedback, and there are synergies between the two. Furthermore, persistent feedback is needed because energy savings can drop when monitors are removed. Frequent accurate billing, rather than estimates, is shown to be effective indirect feedback and, in the UK, historic feedback proves more popular than comparative feedback. ${ }^{75}$ Without better billing, customers may not notice bill reduction. ${ }^{29}$ Relevant up-to-date information combined with better export tariffs (which are starting to appear as discussed earlier) could help realise potential energy savings.

Smart meters are a feedback mechanism that could kick-start an upgrading of the UK's metering system. ${ }^{38}$ Watson et al. ${ }^{38}$ see smart meters as an essential part of a 'reoriented energy market', rather than as an auxiliary purchase with microgeneration units. The Green Alliance ${ }^{52}$ recommends mandatory rolling out of smart metering, reporting that this could deliver 7\% or so of the needed carbon savings from the domestic sector by 2010. However, ownership arrangements need to be sorted out first, and the Green Alliance calls for promoting the meters as an energy-saving device under EECs. The DTI looked into 'field trials that bring together smart meters and microgeneration to the effectiveness of smart meters combined with microgeneration technologies'. ${ }^{40}$ Meanwhile, households installing microgeneration want monitors that show both consumption and production. ${ }^{37}$ Barriers to smart meters come from industry, which sees regulatory obstacles to their expense, such as the 28-day rule for changing suppliers. This is exacerbated by the small size of firms: it is expensive to add consumption information to monitoring devices until the industry grows. ${ }^{37}$ The 28-day rule was scrapped in August 2007. It remains to be seen if this gives a push to the growth of smart meters.

\subsection{Discussion}

There is great potential for microgeneration to play a part in reducing emissions generated by the residential sector. However, strategies designed at maximising uptake will not suffice to maximise energy and emission savings, even with information campaigns. This will only happen with a cultural-behavioural shift in consumers, industry and government.

The current situation can be described as a 'lock-in' in which household energy usage is high and is growing faster than efficiency gains are being made. Furthermore, any energy savings made are lessened by the rebound effect. People feel disempowered about their ability to effect change, expect government to deliver environmental benefits and do not make the connection between personal behaviour and global climate 
change. Industry focuses on maximising sales through a marketing approach, and lacks technical expertise for advice and execution of most efficient installations. A social status has been created in relation to environmental behaviours, including microgeneration, which cannot bring about the necessary change.

From a diffusion of innovation perspective, even successful demonstration projects (such as the PV uptake in Groningen) only affected innovators and early adopters. However, for microgeneration to have a significant impact on the energy system, the mainstream public must be involved. Uptake among the majority would require different strategies and policies, for example social motivations may prevail over technical or environmental factors.

From a transitions theory perspective, we can conclude that system optimisation is not enough. A paradigm shift - a cultural, infrastructural and economic transition - is necessary for microgeneration to maximise environmental benefits and play a part in a broader shift of energy use to more sustainable patterns. Such a shift must be at the cultural and social level, not the individual level.

From a government perspective, various barriers to microgeneration uptake need to be overcome. This will necessitate gaining the public's trust in government policies, sending out clear information and avoiding mixed messages. Such a strategy could include the following.

(a) Ensuring reliable subsidies and clear worthwhile export tariffs are available for consumers. These would help overcome cost barriers, both real and perceived. However, it is also necessary to encourage people to consider long-term savings or revenue from energy.

(b) Engaging with people at local and national levels to increase public understanding of technologies, (re)build trust and increase exposure and familiarity with microgeneration. This could help overcome perceived technical barriers and raise the profile of various microgeneration technologies and their environmental and other benefits.

(c) Ensuring consumers have access to information from independent advisors, as opposed to installers and manufacturers.

(d) Addressing disempowerment among consumers and connecting behaviour at a household level to consequences so people feel they can make a difference and take responsibility for their actions.

(e) Utilising smart meters and other monitoring and good feedback measures to increase information and understanding about energy usage and production.

$(f)$ Engaging industry to deliver improved technical expertise for microgeneration, to ensure installations are appropriate for the sites, to make sure that maintenance is professional and that consumers are given good information to make informed choices. Further changes could include more energy service companies (ESCOs) and a change in industry/consumer relations.

A paradigm shift in the energy culture would lead to new production and consumption models. This could include various ideas, for example empowering consumers to be 'energy citizens' or 'energy co-providers' who play an active role in the energy system, or 'virtual power plants' where microgeneration in individual homes is activated from afar. Further research is needed to check public acceptance of such ideas. New functionalities could emerge in this process, around home production of energy and its sale to a local or national grid or sophisticated energy monitoring and use, although their exact nature would be difficult to determine. Ultimately, a successful paradigm shift would ensure high uptake of microgeneration, increased understanding and awareness of energy production and consumption, and emissions reductions.

\section{CONCLUSIONS}

This paper has reviewed the policy and behavioural aspects of microgeneration, with a particular focus on the UK. Existing policy supports a wide range of carbon prices; however, improvements in clarity are required, particularly with regard to building regulations and the SAP. The CERT is the best directed policy instrument regarding carbon savings, but could be reformulated to ensure absolute carbon reductions are achieved as opposed to reduction over business-as-usual. Regional/local approaches could be effective in promoting uptake, but clarity is required with regard to defining responsibilities.

The behavioural issues pertinent to microgeneration are a potent factor in dictating uptake and use. Most existing microgeneration policy focuses on uptake, and behaviour after uptake is largely ignored. In order to formulate a complete policy framework for accelerating the penetration of microgeneration into the energy generation mix, it is clear that research is required into the policybehaviour interface for successful uptake and application.

Successful uptake of the most appropriate installations with good information provision could maximise emissions savings and increase citizens' awareness of their energy usage and potential savings.

\section{ACKNOWLEDGEMENTS}

The authors would like to acknowledge the United Kingdom Energy Research Centre (UKERC) for funding the activities of the Microgeneration Group.

\section{REFERENCES}

1. Solomon S., Qin D., Manning M., Chen Z., Marquis M., Averyt K. B., Tignor M. and Miller H. L. (eds) IPCC 2007: Summary for policymakers. In Climate Change 2007: The Physical Science Basis. Contribution of Working Group I to the Fourth Assessment Report of the Intergovernmental Panel on Climate Change. Cambridge University Press, Cambridge, 2007.

2. See www.ukerc.ac.uk.

3. DePARTMENT FOR TRADE AND IndUSTRY. Energy White Paper 2003: Our Energy Future - Creating a Low Carbon Economy. The Stationery Office, London, 2003.

4. Climate Change Act 2008: Chapter 27. The Stationery Office, London, 2008.

5. Department for Communities and Local Government. Building a Greener Future: Policy Statement. DCLG, Wetherby, 2007.

6. Climate Change and Sustainable Energy Act 2006. The Stationery Office, London, 2006.

7. Energy Networks Association. ER G83/1 Recommendations for the Connection of Small-scale Embedded Generators (up to 16 A per phase) in Parallel with Public Low-voltage Distribution Networks. ENA, London, 2003. 
8. Office of the Deputy Prime Minister. Building Regulations Approved Document P: Electrical Safety - Dwellings. RIBA Enterprises Ltd, London, 2006.

9. EleXon. Modification Proposal P81: Removal of the Requirement for Half Hourly Metering on Third Party Generators at Domestic Premises, Balancing and Settlement Code. Elexon, London, 2003.

10. Department of Trade and Industry. Microgeneration Strategy. DTI, London, 2006.

11. Department for Business Enterprise and Regulatory Reform. Carbon Buildings Programme. DBERR, London, undated.

12. The Electricity and Gas (Energy Efficiency Obligations) Order 2004. The Stationery Office, London, 2004.

13. The Electricity and Gas (Carbon Emissions Reduction) Order 2008. The Stationery Office, London, 2008.

14. Finance Act 2001. The Stationery Office, London, 2001.

15. The Value Added Tax (Reduced Rate) Order 2004. The Stationery Office, London, 2004.

16. The Value Added Tax (Reduced Rate) (No. 2) Order 2005. The Stationery Office, London, 2005.

17. The Value Added Tax (Reduced Rate) Order 2005. The Stationery Office, London, 2005.

18. Department for Food, Environment and Rural Affairs. Carbon Emissions Reduction Target April 2008 to March 2011: Consultation Proposals. Defra, London, 2007.

19. Finance Bill 2007: Income Tax Exemption for Domestic Microgeneration. The Stationery Office, London, 2007.

20. Finance Bill 2007: Renewables Obligation Certificates for Domestic Microgeneration. The Stationery Office, London, 2007.

21. Her Majesty's Revenue and Customs. Stamp Duty Land Tax: Relief for New Zero Carbon Homes. HMRC, London, 2007.

22. Office of the Deputy Prime Minister. Building Regulations Approved Document L1A: Conservation of Fuel and Power (New Dwellings). RIBA Enterprises Ltd, London, 2006.

23. Office of the Deputy Prime Minister. Building Regulations Approved Document L1B: Conservation of Fuel and Power (Existing Dwellings). RIBA Enterprises Ltd, London, 2006.

24. Sт John Cox C. Compliance with Part L1 of the 2002 Building Regulations (An Investigation into the Reasons for Poor Compliance). Future Energy Solutions, Didcot, 2006, final report EST/OPS/05/068.

25. Department for Communities and Local Government. The Future of the Code for Sustainable Homes - Making a Rating Mandatory: Summary of Responses. DCLG, Wetherby, 2007.

26. Department for Environment, Food and RuRal Affairs. The Government's Standard Assessment Procedure for Energy Rating of Dwellings. Building Research Establishment, Watford, 2005.

27. Hawkes A. D. and LeACH M. A. Cost-effective operating strategy for residential micro-combined heat and power. Energy, 2007, 32, No. 5, 711-723.

28. Peacock A. D. and Newborough M. Impact of micro-CHP systems on domestic sector $\mathrm{CO}_{2}$ emissions. Applied Thermal Engineering, 2005, 25, No. 17-18, 2653-2676.

29. The Carbon TRust. Micro-CHP Accelerator Interim Report, Carbon Trust, London, 2007.

30. Pearsall N. M., Hynes K. M., Martin C. and Munzinger M. Analysis of performance parameters for UK domestic PV systems. Photovoltaic Energy Conversion, Proceedings of the
2006 IEEE 4th World Conference, Hawaii, 2006, 2, 2300-2303.

31. JACKSON T. Motivating Sustainable Consumption - A Review of Evidence on Consumer Behaviour and Behaviour Change. Policy Studies Institute, London 2004, report to the Sustainable Development Research Network.

32. STERN P. C. Towards a coherent theory of environmentally significant behaviour. Journal of Social Issues, 2000, 56, No. 3, 407-424.

33. JAGER W. Stimulating the diffusion of photovoltaic systems: a behavioural perspective. Energy Policy, 2006, 34, No. 14, 1935-1943.

34. OWEns S. and Driffill L. How to Change Attitudes and Behaviours in the Context of Energy, Foresight Review, 2006. See www.foresight.gov.uk/Energy/

How_to_change_attitudes_and_behaviours.pdf for further details. Accessed 18/02/2009.

35. SAUTER R. and WATSON J. Strategies for the deployment of micro-generation: implications for social acceptance. Energy Policy, 2007, 35, No. 5, 2770-2779.

36. WÜSTenhagen R., Wolsink M. and BüRER M. J. Social acceptance of renewable energy innovation: an introduction to the concept. Energy Policy, 2007, 35, No. 5, 2683-2691.

37. KeIRSTEAD J. Behavioural responses to photovoltaic systems in the UK domestic sector. Energy Policy, 2007, 35, No. 8, 4128-4141.

38. Watson J., Sauter R., Bahaj B., James P. A., Myers L. and Wing R. Unlocking the Power House: Policy and System Change for Domestic Micro-generation in the UK. SPRU, Brighton, 2006.

39. Devine-Wright P. Reconsidering Public Attitudes and Public Acceptance of Renewable Energy Technologies: A Critical Review. School of Environment and Development, University of Manchester, 2007, Working paper 1.4 of the research project 'Beyond nimbyism: a multi-disciplinary approach investigation of public engagement with renewable energy technologies'.

40. Department of Trade And Industry. Our Energy Challenge: Power from the People. DTI, London, 2006.

41. Rogers E. M. Diffusion of Innovations. Free Press, New York, 1995.

42. Rotmans J., Kemp R. and Van Asselt M. More evolution than revolution: transition management in public foreign policy. Foresight, 2001, 3, No. 1, 15-31.

43. GeELs F. W. Technological Transitions and System Innovation: A Coevolutionary and Socio-Technical Analysis. Edward Elgar, Cheltenham, 2005.

44. SNYDER D. P. Five meta-trends changing the world. The Futurist, 2004, July-August, 38, No. 4, 22-27.

45. WATSON J. Co-provision in sustainable energy systems: the case of micro-generation. Energy Policy, 2004, 32, No. 17, 1981-1990.

46. Devine-Wright H. and Devine-Wright P. Representing the demand side: 'deficit' beliefs about domestic electricity users. Proceedings of ECEEE 2005 Summer Study Proceedings. European Council for an Energy Efficient Economy, (Bartiaux F. and Selnaes A. G. (eds)), 2005, pp. 1343-1348.

47. Christensen C. M. The Innovator's Dilemma: When New Technology Causes Great Firms to Fail. Harvard Business School Press, Boston, MA, 1997. 
48. Christensen C. M., Anthony S. D. and Roth E. A. Seeing What's Next: Using the Theories of Innovation to Predict Industry Change. Harvard Business School Press, Boston, MA, 2004.

49. JANDA K. Turning solar consumers into solar citizens: strategies for wise energy use. Proceedings of American Solar Energy Society Annual Meeting 2007. ASES, Boulder, CO, 2007.

50. HaAs R., ORnetzeder M., Hametner K., Wroblewski A. and HÜBNER M. Socio-economic aspects of the Autsrian 200 kWp-photovoltaic-rooftop programme. Solar Energy, 1999, 66, No. 3, 183-191.

51. Allegra Strategies. Project Renew: UK Consumer Perspectives on Renewable Energy - Strategic Analysis. Allegra, London, 2006.

52. GreEn Alliance. Achieving a Step-change in Environmental Behaviours. Green Alliance, London, 2006.

53. OXera Consulting Ltd. Policies for Energy Efficiency in the UK Household Sector. Oxera, Oxford, 2006.

54. Whitmarsh L., HaXeltine A., Köhler J., Bergman N. and VALKeRING P. Simulating Consumer Decision-making in Transitions to Sustainable Transport. University of East Anglia, Norwich, 2006, MATISSE WP9 18 month report.

55. Ellison G. Renewable Energy Survey 2004: Draft Summary Report of Findings. ORC International, London, 2004.

56. OfGEM. Review of the Market for Exported Electricity from Microgeneration. Ofgem, London, 2008.

57. See http://www.good-energy.co.uk/.

58. See http://www.ebico.co.uk/.

59. OfGEM. Ofgem's Response to BERR Consultation on Reform of the Renewables Obligation. Ofgem, London, 2007.

60. European Photovoltaic Industry Association. European PV Association's Position Paper on a Feed-in Tariff for Photovoltaic Solar Electricity. EPIA, Brussels, 2005.

61. Mitchell C., Bauknecht D. and Connor P. M. Effectiveness through risk reduction: a comparison of the renewable obligation in England and Wales and the feed-in system in Germany. Energy Policy, 2006, 34, No. 3, 297-305.

62. Doвbyn J. and Thомаs G. Seeing the Light: The Impact of Micro-generation on our Use of Energy. Sustainable Consumption Roundtable, London, 2005.

63. FISCHER C. From consumers to operators: the role of micro CHP users. In Microgeneration: Towards a Decentralized
Energy Supply (Pehnt M., CAmes M. and Fischer C. (eds)). Springer, Heidelberg, 2006, pp. 117-141.

64. JARDINE C. Performance of West Oxfordshire District Council Office's Photovoltaic Arrays, PVSAT3. Durham University, Durham, 2007.

65. Energy Saving Trust. Generating the Future: An Analysis of Policy Interventions to Achieve Widespread Microgeneration Penetration. Energy Saving Trust, London, 2007.

66. London Renewables. Attitudes to Renewable Energy in London: Public and Stakeholder Opinion and the Scope for Progress. Greater London Authority, London, 2003, report carried out by Brook Lyndhurst Ltd in association with MORI and Upstream.

67. CROMPTON T. Weathercocks \& Signposts: The Environment Movement at a Crossroads. WWF-UK, Godalming, 2008.

68. NHBC Foundation. A Review of Microgeneration and Renewable Energy Technologies. IHS BRE Press, Bracknell, 2008.

69. BibBIngs J. Powerhouses? Widening Microgeneration in Wales. Welsh Consumer Council, Cardiff, 2006.

70. Suarez F. F. and UtTerback J. M. Dominant designs and the survival of firms. Strategic Management Journal, 1995, 16, No. 6, 415-430.

71. See www.eonenergy.com/At-Home/Products/Technology_ And_Initiatives/WhisperGen.htm. Accessed 26/02/2009.

72. BaKer P., Barton J., Bergman N., Blanchard R., BRANDON N. P., Brett D. J. L., HaWKe A. S, Infield D., JARdine C., Kelly N., Leach M., Matian M., Peacock A. D., Staffell I., Sudtharalingam S. and Woodman B. UK microgeneration. Part II: technologies. In preparation.

73. Caird S., Roy R. and Herring H. Improving the energy performance of UK households: results from surveys of consumer adoption and use of low- and zero-carbon technologies. Energy Efficiency, 2008, 1, No. 2, 149-166.

74. SORRELl S. The Rebound Effect: An Assessment of the Evidence for Economy-wide Energy Savings from Improved Energy Efficiency. UK Energy Research Centre, London, 2007.

75. Darby S. The Effectiveness of Feedback on Energy Consumption. A Review for Defra of the Literature on Metering, Billing and Direct Displays. Environmental Change Institute, University of Oxford, 2006.

\section{What do you think?}

To comment on this paper, please email up to 500 words to the editor at journals@ice.org.uk

Proceedings journals rely entirely on contributions sent in by civil engineers and related professionals, academics and students. Papers should be 2000-5000 words long, with adequate illustrations and references. Please visit www.thomastelford.com/journals for author guidelines and further details. 